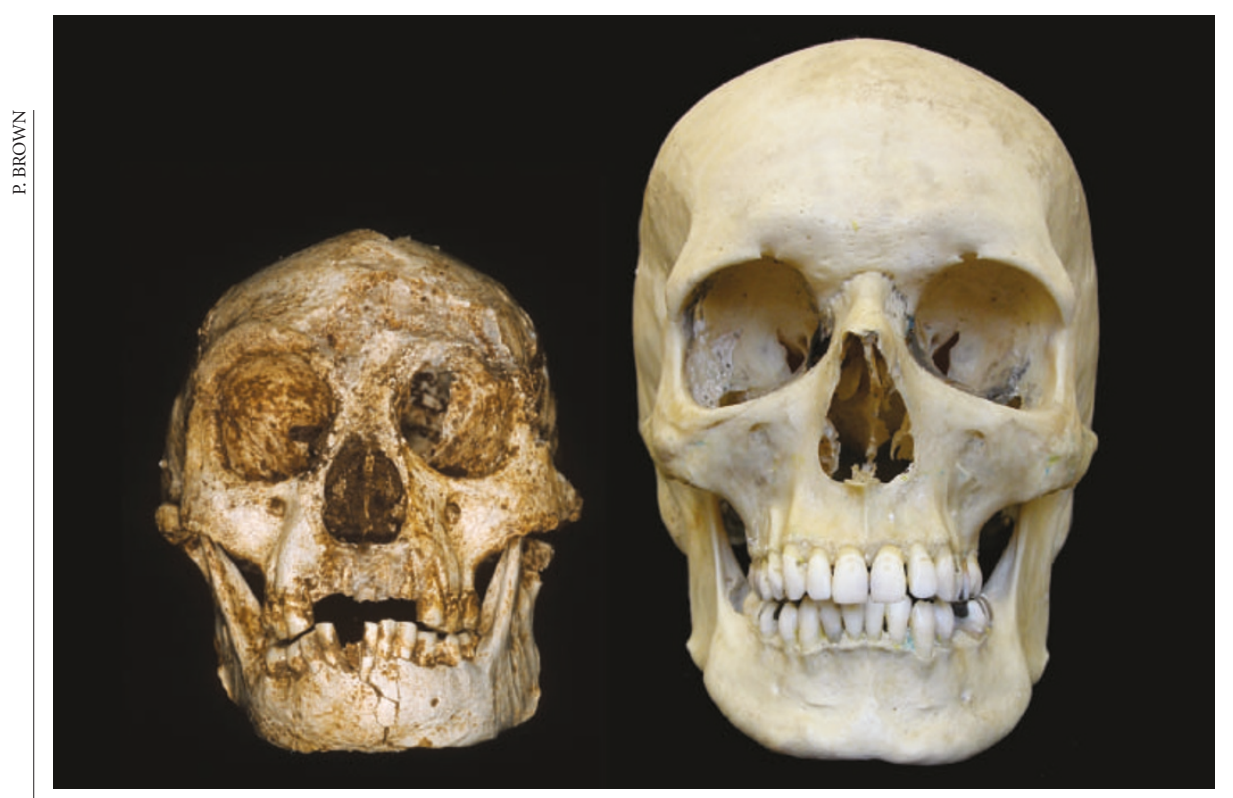

Small skull, big discovery: Homo floresiensis (left) represents a new branch of human evolution.

\title{
Fossil finders in tug of war over analysis of hobbit bones
}

\section{Rex Dalton, Jakarta}

The prized bones of a miniature hominin have finally been returned to the scientists who discovered them, after months of dispute with a competing scientist who had taken them away.

The move is being seen as a victory by the discovery team. But some samples have yet to be given back. And a quarrel over whether the find really represents a new species continues to haunt the researchers.

"It is a complete circus," says Peter Brown, an Australian palaeoanthropologist who co-led the Indonesian-Australian team that reported the discovery last autumn ${ }^{1,2}$.

The skeletal remains are those of Homo floresiensis, a metre-tall hominin species nicknamed 'hobbit', whose discovery revealed a new branch of the human evolutionary tree. The bones, found on the island of Flores, Indonesia, were dated to the unexpectedly recent time of just 18,000 years ago.

Within a month of the publication, one of Indonesia's top anthropologists, Teuku Jacob of Gajah Mada University, had taken the bones to his lab for analysis. These included the skeletal remains of eight individuals, some of which have yet to be described officially. Jacob was given access to the fossils by his friend and co-leader of the discovery team, archaeologist Radien Soejono of the Indonesian Centre for Archaeology in Jakarta.

The rest of the discovery team, also led by archaeologist Michael Morwood of the University of New England in Armidale, Australia, was furious that Jacob had removed the remains.

Tensions built as Jacob began saying publicly that $H$. floresiensis was not a new human species. He contends that the bones are from
Homo sapiens pygmies. The one dwarfed skull could be explained by a congenital defect, Jacob says. Many other leading palaeoanthropologists, including Tim White of the University of California, Berkeley, and Chris Stringer of the Natural History Museum in London, disagree with Jacob's interpretation.

The dispute worsened when Jacob gave two other researchers access to the bones for a week in February. Morwood and Brown call the examination of samples about which they have not yet published "unethical". But the researchers in question - Alan Thorne, a semi-retired anthropologist from the Australian National University in Canberra, and anatomist Maciej Henneberg of the University of Adelaide - say they only looked briefly at these specimens and deny any improper conduct.

Jacob promised to return the bones in both January and February, by deadlines agreed with the Indonesian Centre. But he twice failed to do so, saying that he had not finished with the remains. On 23 February, the bones were at last returned to the centre, where they are being held under lock and key.

But some samples remain elsewhere. Pieces of rib bone given out by Jacob for genetic analysis are still at the Max Planck Institute for Evolutionary Anthropology in Leipzig, Germany, and at another lab in Jakarta. If successful, analysis of DNA should help to pin down the evolution of the species.

The discovery team is demanding that this material also be returned immediately. In the meantime, the researchers are in Indonesia looking for more bones to verify and expand their theories.

$\square$

1. Brown, P. et al. Nature 431, 1055-1061 (2004).

2. Morwood, M. J. et al. Nature 431, 1087-1091 (2004).
France lays plans for premier cancer centre in Toulouse

Alison Abbott, Toulouse

Europe's largest centre for cancer research is to be built on the site of a major chemical explosion in France.

More than 30 people died and thousands were injured on 21 September 2001 in a blast at the Toulouse chemical company AZF. The explosion was one of Europe's worst industrial accidents.

The cancer centre will form the heart of one of France's seven new 'Cancéropôles' - regional networks of cancer research and care.

The 220-hectare site will house many cancer-research groups and institutes that are currently scattered throughout the city, as well as some hospital departments. These will benefit from shared facilities, including sophisticated genomics and microscopy equipment. An institute for advanced techniques in life sciences, employing physicists, chemists and computer scientists, will also be built.

The entire project is being directed by Georges Delsol, a cancer researcher at Purpan University Hospital, Toulouse. "The explosion was not only a terrible human tragedy, but it also threatened the long-term economic well-being of the city," says Delsol. “The Cancéropôle will bring new jobs as well as being very good for science."

Planned public investment in plant and equipment at the site will total about $€ 600$ million (US\$800 million). Two French pharmaceutical companies Sanofi-Aventis and Pierre Fabre - will also move to the site, and say that they plan to build labs to develop new drugs, partly on the basis of the cancer research that will also take place there.

But first the land must be cleaned up. The explosion occurred in a store containing hundreds of tonnes of chemicals for fertilizer production. Total, AZF's parent company, is organizing and financing the clean-up of the pollutants - predominantly ammonia, ammonium nitrates and chlorine. It is selling the land to the Cancéropôle for the symbolic price of 'one franc'.

The ministry of defence, which still owns adjacent land used as a military dump, is cleaning that up and will also sell it cheaply to the Cancéropôle.

Building work will start in earnest next year, and the facility should be opened in 2008, when it will employ up to 2,500 people. 